\title{
A Disagreeable Text
}

\section{The Uncovered First Draft of Bryan Edwards's Preface to The History of the British West Indies, $c .1792$}

\author{
Devin Leigh \\ Department of History, University of California, Davis, \\ Davis, CA, USA \\ dtleigh@ucdavis.edu
}

\begin{abstract}
Bryan Edwards's The History of the British West Indies is a text well known to historians of the Caribbean and the early modern Atlantic World. First published in 1793, the work is widely considered to be a classic of British Caribbean literature. This article introduces an unpublished first draft of Edwards's preface to that work. Housed in the archives of the West India Committee in Westminster, England, this preface has never been published or fully analyzed by scholars in print. It offers valuable insight into the production of West Indian history at the end of the eighteenth century. In particular, it shows how colonial planters confronted the challenges of their day by attempting to wrest the practice of writing West Indian history from their critics in Great Britain. Unlike these metropolitan writers, Edwards had lived in the West Indian colonies for many years. He positioned his personal experience as being a primary source of his historical legitimacy.
\end{abstract}

\section{Keywords}

Bryan Edwards - West Indian history - eighteenth century - slavery - abolition

Bryan Edwards's The History, Civil and Commercial, of the British Colonies in the West Indies is a text well known to scholars of the Caribbean (Edwards 1793). First published in June of 1793, the text was "among the most widely read and influential accounts of the British Caribbean for generations" (V. Brown 2020:233). This article introduces an uncovered first draft of Edwards's preface 




FIGURES 1-2 Title page and first page of draft preface

In an attempt to obtain more information on the West Indies from gentlemen he knew in Britain, Edwards printed off an early draft of the preface to his History. The draft shows details that were eventually changed, including the title of the History itself. “Title Page and First Page to Bryan Edwards's Draft Preface to the History of the British West Indies, c. 1792," exact date unknown, ICs 96, 3, 4, the West India Committee, Westminster.

(C) THE WEST INDIA COMMITTEE (ICS 96, 3, 4) 


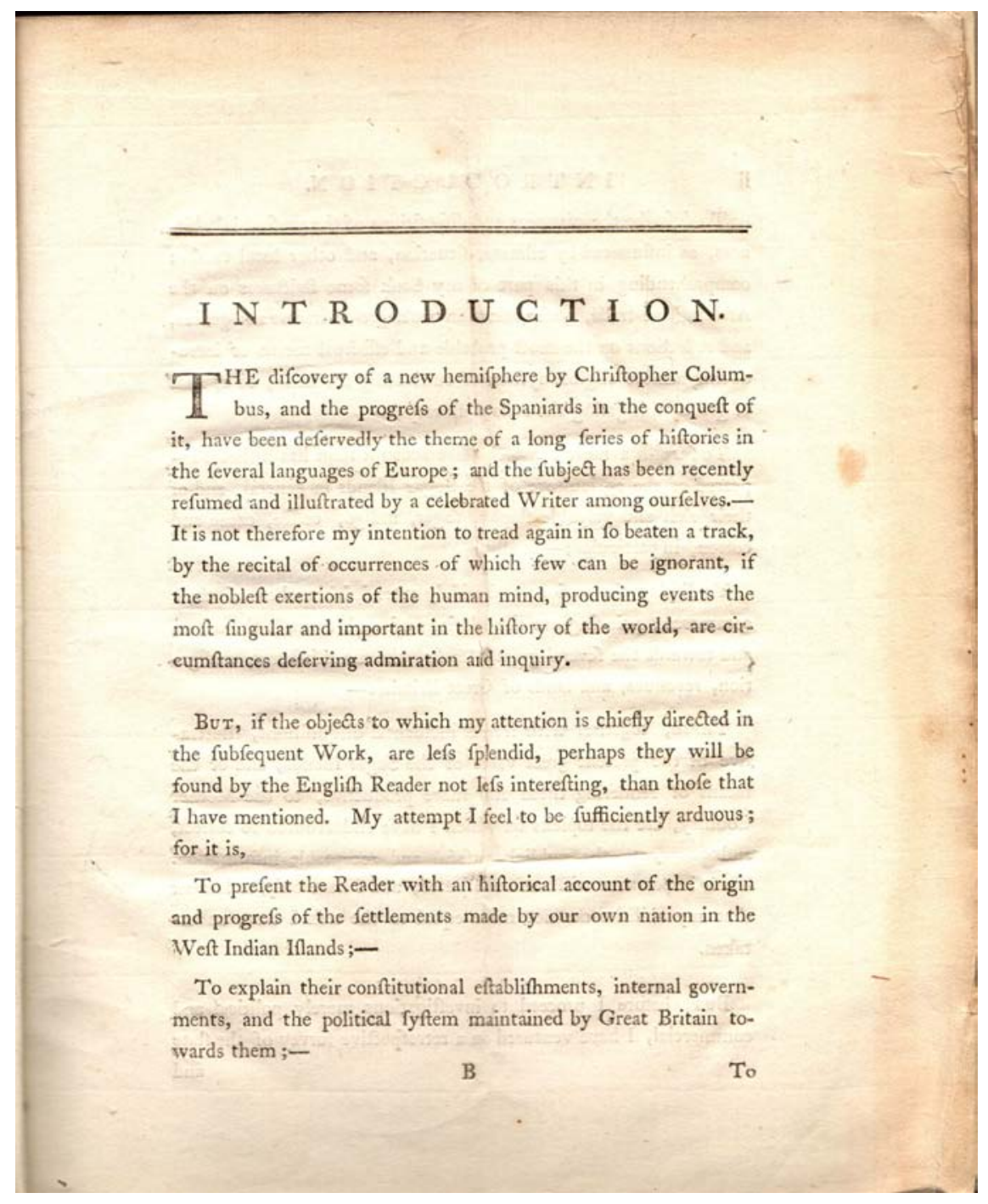


to that work. ${ }^{1}$ The preface is embedded in a letter that Edwards sent to his friend Edward Long, a contemporary British colonist and historian of Jamaica, and housed in the archives of the West India Committee (or wIC) in Westminster, England. To my knowledge, the document has never been published before or fully analyzed in print by scholars. ${ }^{2}$ The exact date of this document is a mystery. However, it was almost certainly written by Edwards in Britain, sometime between May of 1792 and May of 1793. It is 18 pages long, and it differs significantly from the version that Edwards printed in his History. ${ }^{3}$ More specifically, the draft contains 14 paragraphs' worth of material that Edwards deleted for his final preface, as well as a number of line edits and sentences that he redacted throughout. It omits another eight paragraphs and a handful of small edits that Edwards added to his final draft.

This article begins by offering some brief suggestions about how Edwards's draft fits in with our current understanding of West Indian history. It then provides contextual information on Edwards's History and life. Finally, it analyzes Edwards's draft by concentrating on three interconnected themes: natural history, colonial degeneracy, and abolition. By reviewing the material that Edwards created for this draft but then deleted, the article suggests that we gain valuable insight into the writing of West Indian history at the end of the eighteenth century. In particular, we can see that Edwards was an example of a colonial intellectual responding to the challenges of his day, a period that historians have long defined as the beginnings of the "fall of the planter class" (Petley 2012). Seen in this context, Edwards's preface testifies to a broader desire among colonists at the end of the eighteenth century to seize the practice of writing West Indian history from authors based in Great Britain. The latter authors had dominated the production of West Indian history for over a century, but their work had recently become hostile to the planter class.

1 The full citation for this source is Bryan Edwards, "Introduction to An Historical, Political, and Commercial Survey of the West India Islands," i-xviii, in letter of Bryan Edwards to Edward Long, c. 1792, exact date unknown, ICs 96, 3, 4, the Archives of the West India Committee, Westminster, London.

2 I have encountered only one other source that has analyzed Edwards's draft preface, and this source remains unpublished. See Scott 2008:50-57. I am grateful to Scott for sharing this excellent work with me.

3 For the publication of Edwards's History, see Diary or Woodfall's Register, June 10, 1793. 
The analysis of new source materials from Caribbean authors can lead to new discoveries about how West Indian history was produced in the early modern era. For example, Richard and Sally Price made significant discoveries about West Indian history after studying the manuscript and journals of the colonial soldier John Gabriel Stedman. These materials were used as the basis of Stedman's classic 1796 Narrative, which depicts his years as a resident in the Dutch colony of Suriname in the 1770s (Stedman 1796; Price \& Price 1988 and 1992). In particular, the Prices showed how Stedman's publishers censured his outrage at the horrors of colonial slavery and his general indictment of the plantation system. As in the case of Stedman, Edwards's draft preface is also an example of how criticisms of colonial slavery were censored in Britain during the age of abolition. One important difference, however, is that Edwards was probably more involved in censoring himself. Unlike Stedman, who famously rejected an early version of the work that bore his name as being "full of lies and nonsense" (Price \& Price 1988:L), Edwards was tremendously proud of his final work. He had succeeded in advancing his personal reputation in Britain as a gentleman scholar without severing his close ties to the proslavery community.

Edwards's draft also offers an opportunity for historians to revisit the geography of West Indian history during the early modern era. Understandably, most work on the historiography of the British West Indies has focused on the twentieth century, when the production of history was professionalized as an academic discipline and those able to practice it became increasingly more diverse. The result is that many scholars still turn to Elsa Goveia's groundbreaking 1956 study as the best survey of West Indian historiography up to the year 1900. In 1966, D.A.G. Waddell categorized the historiography of the West Indies into three distinct phases which have largely been followed by other historians. In this schema, Waddell lumped the first four centuries of European colonization into the first phase (Waddell 1966:344). During this extended period, he presented the production of West Indian history as being undertaken by "amateurs" who were "usually either West Indians of the ruling class, or British sojourners in the West Indies, whose interests were primarily local and whose main qualifications were local knowledge and experience." Although this assessment may apply well to the nineteenth century, it does not suffice as an explanation for the late seventeenth and eighteenth centuries. More to the point, it cannot account for the production of Edwards's History. Edwards was compelled to produce his History by the fact that he understood Caribbean writing as not dominated by "West Indians of the ruling class." 
The age of abolition is the immediate context for Edwards's History. As historians have long demonstrated, West Indian colonists in the British Empire faced a series of new pressures in the 178 os and 179os. Although there were antecedents - the polemics of moral philosophers like Montesquieu, the indictments of religious leaders like John Woolman, or the lawsuits of activists like Granville Sharp - these pressures reached a profound new level in the late ${ }^{1780 s .}{ }^{4}$ In 1788 , the British government launched its first official investigation into the morality of the transatlantic slave trade (Swaminathan 2009:8). For the next five years, bodies of the government investigated the slave trade, lending greater attention to attacks on slavery and its colonial practitioners. By one estimation, more than 51,000 pamphlets or books and over 26 ,ooo reports were printed by the investigative committee in only the first year of the inquiry (K.W. Lewis 2017:51). In short, the age in which Edwards produced his History witnessed the "first serious challenges" to the wealth and power that British planters had accrued over the previous century (Petley 2012:2).

The challenges that planters like Edwards faced in the late eighteenth century were diverse. They were economic, political, intellectual, and cultural. They included, for example, the passage of higher duties on sugar that undermined planter profits; the implementation of mercantilist policies in new ways that threatened West Indian imports; the elaboration of new ideologies that presented slave-owning as unprofitable; and the dissemination of propaganda that portrayed planters as being backward, savage, violent, and irrational citizens of the British Empire. ${ }^{5}$ While Africans and people of African descent had been resisting their own enslavement since the beginnings of the transatlantic slave trade, these new pressures in Britain coincided with a rise in acts of resistance, both violent and nonviolent, by free and enslaved people in the Caribbean. By the time that Edwards wrote this draft in 1792, the Haitian Revolution had dramatically elevated threats to the British planter class (Geggus 2001; Blouet 2001; V. Brown 2020:233-34). ${ }^{6}$

4 John Woolman was an eighteenth-century Quaker and merchant from the North American colonies. He published a series of antislavery essays in the 175 os and 1760 os, and is generally regarded as one of the earliest and most outspoken critics of colonial slavery in the British Empire. Granville Sharp was a British clerk who became one of the most prominent abolitionists in the British Empire. He began a career as an abolitionist in the late 176os, when he started lobbying for the rights of enslaved people who had run away from their masters in London.

5 For overviews of these challenges, see Anstey 1975:95-123; Davis 1975; Petley 2018; and Sypher 1942:25-100.

6 A note on the relationship between Edwards's History and the Haitian Revolution. Historians 
Like other colonial intellectuals during this era, particularly the Mexican Francisco Javier Clavijero, the Virginian Thomas Jefferson, and the Martinican Moreau de St. Méry, Edwards envisioned his History as an opportunity to address criticisms he perceived to be threatening the authority of the white creole class (Brading 1991; Dugatkin 20o9; Fabella 2010). Broadly speaking, he attempted to wrest control of the writing of West Indian history from the pens of metropolitan authors who had long dominated the practice from Europe. As this article will reveal, he did this by dismissing natural history, hitherto the field's predominant genre; rejecting the production of Caribbean scholarship by noncolonial writers; and adopting a Jeffersonian view of West Indian slavery that shifted the blame for the transatlantic slave trade, then the era's most controversial political issue, away from colonial residents. By either tempering or silencing these critiques in his final preface, Edwards revealed that he could not easily escape the social pressures of his age. Gentleman scholars of the late eighteenth century placed an increasing value on one's "civility," "politeness," and "agreeableness" in both person and in print (Thomas 2018). Ultimately, it is important to know that Edwards capitulated to these social pressures. His criticisms and compromises, when looked at together, remind us that the transformation of British West Indian scholarship was a contested process. The writing of West Indian history did not shed its eighteenth-century conventions as easily as contemporaries like Bryan Edwards had hoped.

\section{Bryan Edwards and The History of the British West Indies}

First published in two volumes in 1793, by John Stockdale in London and Luke White in Dublin, Edwards's History became an instant bestseller. Already by December 1793, roughly six months after the text was first published, Edwards wrote to Long that "My Book has sold beyond expectation, and the printer presses hard for a corrected Copy, that a new Edition may appear in the course of January" (Howard 1925, vol. 1:294). That second edition appeared in 1794,

like Olwyn Blouet have observed that Edwards barely mentioned the ongoing Haitian Revolution in his History (Blouet 2001:48). He also did not mention it in this draft. This might seem strange because Edwards had a personal encounter with the Haitian Revolution in the fall of 1791, and he would think and write much about the event in the ensuing years. The answer appears to be that Edwards had largely finished composing his History by April of 1791, four months before the outbreak of the revolution. For evidence supporting this claim, see letter of Thomas Dancer to Edward Long, April 13, 1791, Correspondence with Thomas Dancer, Add. MS 22678, British Library, fol. $59^{\mathrm{r}}-59^{\mathrm{v}}$. 
with three more editions being printed after Edwards's passing on July 16, $1800{ }^{7}$ These editions appeared in 1801, 1807, and 1819. Moreover, the work was translated into five European languages. By its fifth edition, it had swelled to five separate volumes, including new materials added from Edwards's later writings and from the writings of his close friend Sir William Young. When first published, the History legitimized Edwards in Britain's scholarly community. It provided the basis for his election to the Royal Society-the most prestigious and exclusive scientific institution in Britain-in $1794 .{ }^{8}$ More than likely, it also played a role in his election to Parliament in 1796 and his nomination to the prestigious African Association that same year. Others who wrote on the British West Indies in the late eighteenth and early nineteenth centuries regarded Edwards's History as being one of the most authoritative and comprehensive works available on the region (Moseley 1799:171-72; Poyer 1808:xiv; Young 1801:v-viii).

This fame carried over into the age of professionalized history. An early historian of the West Indies, Lowell Ragatz, characterized Edwards's History at the start of the twentieth century as "the best book on the subject up to the close of the eighteenth century" as well as a "classic in British Caribbean literature and probably the most famous work in the field" (Ragatz 1932:165). Historians have reaffirmed this reputation ever since. ${ }^{9}$ What made Edwards's work so important was that he treated the entire British West Indies, as opposed to a single island, from the colonial point of view. Other writers of his centurysuch as Hans Sloane on Jamaica, William Smith on Nevis, or Griffith Hughes on Barbados-concentrated on individual colonies (Sloane 1707; Smith 1745; Hughes 1750). They followed in a British tradition of West Indian "local history," practiced since at least the mid-seventeenth century by travelers such as Richard Ligon (Ligon 1657; Goveia 1956:34-64). In addition, scholars have valued Edwards's History because it was less outwardly racist than certain contemporary histories, most notably The History of Jamaica by Long (1774). Historians generally interpret Edwards's History as being a far more "humane" and "moderate" work and, thus, a more "objective" study of West Indian society. ${ }^{10}$

7 The Gentleman's Magazine 70, Part 2 (180o), pp. 702, 793-94.

8 Bryan Edwards's Certificate of Election, Archives of the Royal Society, May 22, 1794, G B 117, EC/1794/o1.

9 For examples of scholars who have demonstrated the value of Edwards's History, see Williams 1944:266; Goveia 1956:63; Walvin 1972:116; Sheridan 1974:2; Griffith 1993:206; Higman 1999:49-51; Burnard 2004:246; and, most recently, Newman 2018:151. For an analysis of Edwards's intellectual legacy, see Scott 2008:95-119.

10 For a selection of writers who have presented Edwards's History as "humane" or "moderate," see Young 1819, "Prefatory Advertisement," p. v; Goveia 1956:8o-9o, 47, 53, 63-64, 75, 
Notably, Edwards was the first person to publish a general history of the British West Indies who actually resided there and called it home. Not one of his predecessors-Samuel Clarke, Richard Blome, Robert Burton, John Oldmixon, Edmund Burke, the Abbé Raynal, and William Robertson-appears to have visited the West Indies. ${ }^{11}$ None of them wrote from personal experience or firsthand knowledge. Since about the 1670s, those who attempted to survey the British West Indies, such as Burke, did so in an older intellectual tradition of compilers like Richard Hakluyt and Samuel Purchas. These men have been called "stay-at-home royal chroniclers" (Bauer 2003:79). They surveyed firsthand travel accounts but did not see their own firsthand experience as essential to the historian's craft (Bauer 2003:88-89). In the opening of his two-volume text, The British Empire in America, Oldmixon expressed a different view. He regretted that he "never was in America." He clarified that he thought "an exact History of all the British Empire in the West-Indies" demanded that "Men of Interest and Capacity would write it on the Spot." Such an historical work really "should," in Oldmixon's mind, "be undertaken in the Plantations" by a writer who actually called them home (Oldmixon 1708, vol. 1:vii).

Edwards became the historian that Oldmixon had called for back in 1708 . This fact was not lost on him. To the contrary, it was one of the primary reasons that he undertook his publication. Indeed, Edwards was one of those proslavery writers characterized by Srividhya Swaminathan as valuing "personal experience" as a "powerful rhetorical strategy," and who emphasized their "local authenticity and eyewitness testimony" (Swaminathan 2009:143). Throughout the late eighteenth century, proslavery authors like Edwards often combined their "firsthand recollections, anecdotes, and observations" with attacks on "abolitionist writers for their general lack of firsthand knowledge, foresight, or evidence" (Dumas 2016:60, 56). As scholars like the historian Barry Higman have long noted, it is no coincidence that the late eighteenth century saw a rise in histories of the British West Indies composed by "members of the plantermerchant class," at exactly the same moment that this class was coming under greater attack back in Europe (Higman 1999:50). In this way, colonial historians like Edwards are an example of those whom David Brading has described

169, 173, and 174; Jordan 1968:175; Thorne 1970:2; Davis 1975:190-95; Barker 1978:166, 18687; Dayan 1995:147; Blouet 2000:215; G. Lewis 2000:557; Sheridan 2008:2; and Boulukos 2008:202.

11 Clarke 1670; Blome 1672; Burton 1685; Oldmixon 1708; Burke 1757; Raynal 1777; and W. Robertson 1777. A similar point can be made about historical atlases of the British West Indies, which were often compiled by metropolitan cartographers who had not seen the colonies. For an example, see Jefferys 1780 . 
as "creole patriots" and whom Jorge Cañizares-Esguerra has described as "patriotic epistemologists" (Brading 1991; Cañizares-Esguerra 2001). They wrote in an effort to redirect the geopolitics of knowledge production away from Europe.

Edwards was born on May 21, 1743, in the village of Westbury, in the county of Wiltshire, England..$^{12}$ His father died when he was thirteen years old, around which time Edwards's mother sent him to Jamaica to live with her brother, a wealthy planter named Zachary Bayly. Edwards lived in Jamaica, in the environs of Kingston, from 1759 to $1774 .{ }^{13}$ During these years, he became a slaveowner and began his service with the Jamaican legislature, two features which informed his political activity for the rest of his life. In 1774 , he returned to Britain for a period of thirteen years. In 1787 , he came back to Jamaica a second time, now living mostly at two estates gifted by his uncle, Bryan Castle and Brampton Bryan, in the recently formed Trelawny Parish. ${ }^{14}$ He stayed until 1792,

12 For sources on Edwards's life, see Bird 2007:27-46; Blouet 200o:215-22; Blouet 2001: 44-57; Cundall 1915:307-18; Davis 1975:164-212; Edwards 1801, vol. 1:ix-xiv; Saxe 1971; Scott 2008; Sheridan 2008; Thorne 1970; Vendryes 1945; Williamson 2011; and Wright 1966:297. For an image of Edwards, see Lemuel Francis Abbott, Portrait of Bryan Edwards, Archives of the Royal Society of London. The image of Edwards on the frontispiece to the 1807 edition of the History of the British West Indies is a line engraving of this painting by Thomas Holloway, now housed in the National Portrait Gallery, London, call no. NPG D7726. For his probate record, see "Will of Bryan Edwards of Polygon, Southampton, Hampshire," TNA Рвов $11 / 1346 / 85$.

13 For Edwards's residence in Kingston, see Bryan Edwards, Marginal Notes to Edward Long's The History of Jamaica, the West Indies Special Collection, Mona Library, Jamaica, F1868.L84, vol. 2:109 and vol. 3:852. Edwards notes that he had lived "fifteen years in this neighborhood" (cf. Edwards 1793, vol. 1:16-17) and he had "eighteen years [of] residence there." There is also evidence in the Kingston Vestry Minutes, 2/6/4, fols. 38 and 77; and 2/6/5, fols. 2 and 15, the National Archives of Jamaica, Spanish Town. These vestry minutes show that Edwards rented a property on Harbour Street in Kingston in the years $1765,1766,1768$, and 1769. Edwards probably lived on his uncle's property of Greenwich Penn, right up the road in St. Andrew's Parish, before 1765 . This property is marked on the following map: Craskell 1763 . It is described in the "Will of Zachary Bayly," TNA, Рвов 11/968/87. Edwards is mentioned as residing at Bayly's Counting House throughout the early years of his residence in the following letter: Simon Taylor to George Hibbert, Kingston, February 19, 1798, ICS, I/B/9. For Edwards's return to Britain in 1774, see notices of his marriage in the British papers. For example, St. James's Chronicle or the British Evening Post, November 12-15, 1774. Historians have generally assumed that Edwards lived in Jamaica for a number of years between 1774 and 1787 , but I have not found evidence of this.

14 Aikman 1811-29, vol. 8:265-66. For an image and a short description of Edwards's residence at the Bryan Castle Great House in Trelawny Parish, see Hakewill 1825. The location of Bryan Castle plantation is marked on the following map in Edwards 1794. It is generally believed that Edwards compiled most of his History in his study at the Bryan Castle Great House. See Cundall 1915:307-8. Although it is not clear exactly when Edwards arrived in 
at which time he repatriated to Britain. This time, he stayed until his death eight years later. In his final preface, Edwards explained of his History: "the first part of the work was written before his Return to the West Indies in the beginning of 1787 ; a considerable part while he was there, and the remainder, with most of the notes, since his return to Great Britain, in the autumn of 1792" (Edwards 1793, vol. 1:xviii). We can have confidence this trajectory is generally accurate because we have copies of Edwards's notes from the 1770s-as well as other works that he wrote in Jamaica in the 1780 - which tested out arguments for his History. ${ }^{15}$

When exactly did Edwards compose this early draft? Without some additional evidence, we can only arrive at an approximate answer. This answer is based upon an educated guess that Edwards drafted the preface in the final third of the timeline described above, after he returned to Britain. Edwards is mentioned at the Jamaican Assembly for the last time on March 15, 1792 (Aikman 1811-1829, vol. 9:102). Previously, he had asked the assembly's leave so that he could return to England to care for his ill health (Aikman 1811-1829, vol. 9:81). When the assembly started meeting again, on May 1, 1792, he was not present. This suggests that Edwards left Jamaica between March 15 and May 1, a range confirmed by a letter that he sent to James Adair in $1794 .{ }^{16}$ Assuming that his trip from Jamaica took roughly four weeks, this means that Edwards arrived in Britain by early May 1792, and that he had a little over a year to prepare his History for the press. ${ }^{17}$ It was almost certainly during this time frame that he wrote

Jamaica, it must have been by June. See the following letter: Bryan Edwards to Edward

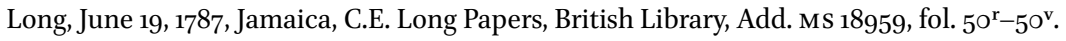

15 For Edwards's notes for his History from the 1770s, see Bryan Edwards, Marginal Notes to Edward Long's The History of Jamaica, the West Indies Special Collection, Mona Library, Jamaica, F1868.L84, vol. 1:128. Edwards refers to the "present" as 1779. For the two publications, see Jamaican Assembly 1789 and Edwards 1789. Although Edwards is not listed as the author of the first publication, he was singled out for his work on it by the speaker of the assembly. See Aikman 1811-1829, vol. 8:438. See also the following letter for mention of Edwards's work on his History while he was living in Jamaica in the late 178 os and early 179os: Thomas Dancer to Edward Long, April 13, 1791, C.E. Long Papers, British Library, Add. MS 22678 , fols. $59^{\mathrm{r}}-59^{\mathrm{v}}$.

16 Bryan Edwards to James Adair, August 12, 1794, Polygon Southampton, The Adair Papers, British Library, Add. MS 53804, fols. $19 \mathrm{o}^{\mathrm{r}}-9^{\mathrm{r}}{ }^{\mathrm{r}}$. Edwards says he returned from Jamaica "about sixteen months ago."

17 As previously mentioned, the work was first advertised as published on June 10, 1793; however, the dedication was dated on June 3 and the newspapers said that the work was presented to the King a few days later. See London Chronicle, June 6-8, 1793. The publisher had run ads declaring that he would print the History earlier, especially on May 20, but it appears that none of these earlier deadlines were actually met. 


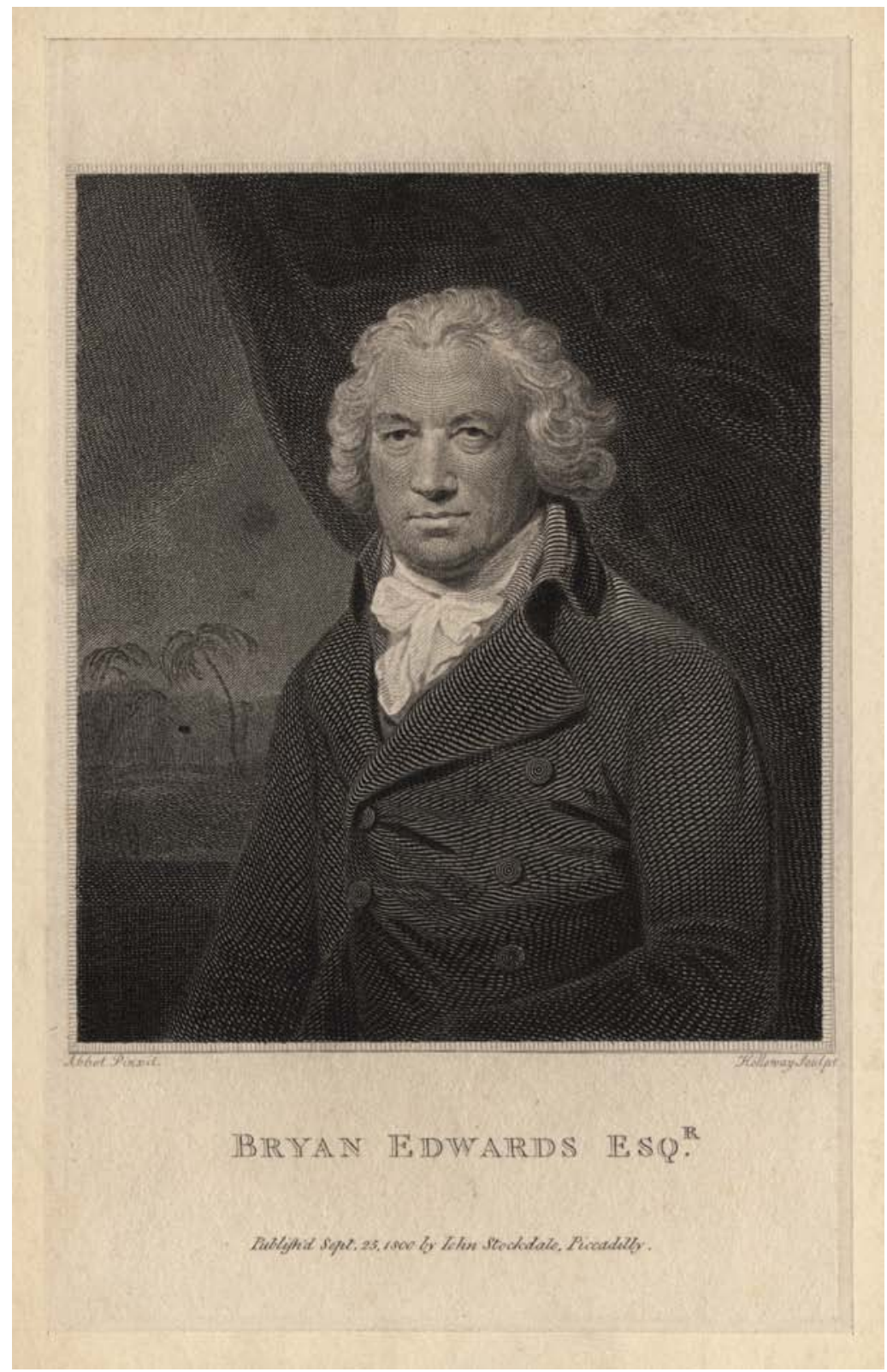

FIGURE 3 Portrait of Bryan Edwards

Bryan Edwards has been called one of the most important historians of the British West Indies in the early modern period. This line engraving of him was done by Thomas Holloway, after a painting by Lemuel Francis Abbot, ca. 1800 .

(C) THE NATIONAL PORTRAIT GALLERY (NPG D7726) 


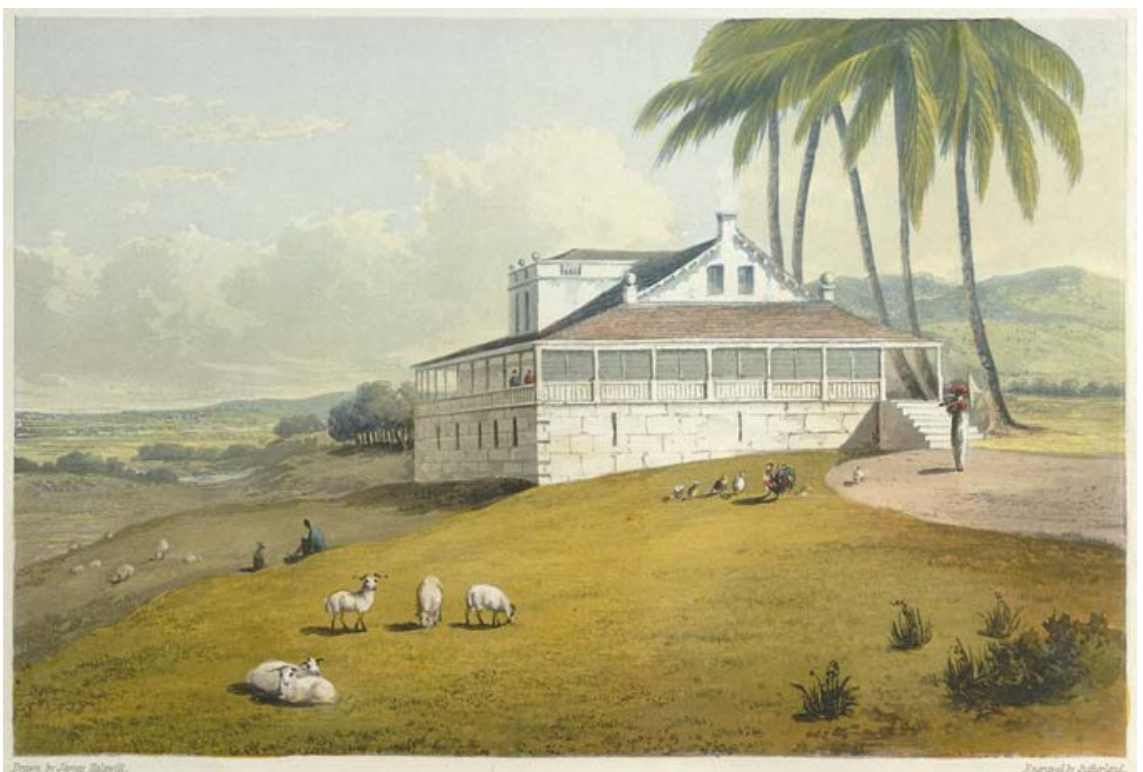

FIGURE 4 Print of Bryan Castle

Edwards viewed his long residence in the Caribbean as being a source of legitimacy for his work as a West Indian historian. The idealized image here shows one of his estates in Trelawny Parish, Jamaica, where he wrote much of his History between the years 1787 and 1792. "View of Bryan Castle Great House, Trelawny." In James Hakewill, A Picturesque Tour of the Island of Jamaica (London: Hurst and Robinson, 1825), no page.

(C) BRITISH LIBRARY BOARD (1486.GG.11 PLATE 27)

the draft of his preface under review here. At the time, he called it an "introduction" rather than a preface. In fact, the whole History had a proposed title that differed from the one he would ultimately choose. It was called An Historical, Political, and Commercial Survey of the West Indian Islands, Chiefly Those of Great Britain.

The letter that Edwards wrote to Long, which accompanies this draft, provides additional insight into the context of its creation. At the time, Edwards was living at a hotel on Jermyn Street in Westminster. This residence was likely associated with some maneuvers he was making to enter Parliament, described more fully in his letter to Adair. ${ }^{18}$ As he mentions, Edwards was traveling to and from Bristol at the time, perhaps visiting places associated with his youth. ${ }^{19}$ He mailed the letter to Long's city address at Wimpole Street (Howard 1925,

18 Bryan Edwards to James Adair, August 12, 1794 (see note 16).

19 Edwards attended several schools in Bristol before he headed to Jamaica. Edwards, "Sketch 
vol. 2:358-61). He stated that he had been busy working on his History since returning from Jamaica. "I have applied so closely to my intended publication," he wrote, "that it really begins to make a figure-a voluminous one I mean." He said that he was looking for information on the Windward Islands, but all of his potential informants - gentlemen associated with those islands-had asked him for an idea of what shape the text would ultimately take. To accommodate them, Edwards printed off "a sheet or two of the introduction," although only "2O copies so that the whole may be suppressed" if necessary. He inserted one of these copies into his letter to Long. This is the only copy of the draft that survives. It was preserved by Long in his personal papers, and it somehow ended up in the archive of the lobbyist group that both Edwards and Long had participated in, which was then called the Society of West India Planters and Merchants. ${ }^{20}$ The modern version of this group - the WIC—-has preserved Edwards's letter and draft in their collections to this day.

Before analyzing this draft, there are a couple of brief notes that should be made. First, as Edwards implied in his letter to Long, this draft is not the entirety of the introduction he had originally composed. As readers will see, the draft ends abruptly after page 18 . The formatting, with the word "In" hanging at the bottom of the last page, tells us that at least one additional page was written but was either not included in Edwards's letter to Long, or went missing subsequently. In addition, one should explain why the document is cited in this article with an "ICs" abbreviation. The West India Committee papers had been on loan to the Institute of Commonwealth Studies in London. Sometime prior to 2017 , the WIC recalled their archives from this institute with the plan of housing them at their headquarters. Although the wic's materials are now available for researchers to consult in Westminster, for now, this document retains its ICS citation. That may change as the WIC continues to formalize its institutional archive and catalog.

\section{The Trouble with Natural History}

As previously mentioned, Edwards's draft is notable for the way that it challenged dominant conventions of West Indian historiography. The first of these

of the Life of the Author, Written by Himself a Short Time before His Death," (Edwards 1801, vol. 1:ix-xiv). Bristol is about 25 miles northwest of Edwards's hometown of Westbury.

$20 \quad$ Ryden 2009; D. Hall 1971; Penson 1921; and O'Shaughnessy 1997. Long and Edwards had been attending the lobby since at least its consolidation in 1775. See Craftsman or Say's Weekly Journal, December 9, 1775 . 
we will explore here is natural history. When Edwards published his text in 1793, natural history was the most dominant genre of what we would today call nonfiction writing on the West Indies (Bauer 2003; Iannini 2012; Parrish 2006). As a discipline, it followed a strict series of guidelines that were laid down by the leaders of the Royal Society of London during the late seventeenth century (Boyle 1665). These guidelines involved, mainly, the collecting and cataloguing of observations on natural phenomena, particularly flora, fauna, and meteorological events such as earthquakes and hurricanes. To Edwards, this genre was exemplified by the works of British authors such as Sloane, Hughes, and Patrick Browne (Sloane 1707; Hughes 175o; Browne 1756). These authors included extensive lists and images of natural history phenomena from the West Indies in their work. For example, Sloane had inserted "274 detailed copperplate engravings" into his Natural History of Jamaica (Iannini 2012:72). His disciple, the naturalist Mark Catesby, followed in his lead by including 220 color plates in his Natural History of Carolina, Florida, and the Bahama Islands (Catesby 1747; Iannini 2012:73). To some extent, Edwards adhered to this tradition. He published a catalog of "exotic plants" from Jamaica, which he named Hortus Eastensis, as an appendix to the first volume of his History (Edwards 1793, vol. 1:455-89).

Nonetheless, Edwards dismissed this tradition of West Indian scholarship in his draft. "Physiologists indeed have not been wanting," he said, "who have treated of vegetable productions, from the cedar to the hyssop, with sufficient minuteness of description." His use of this phrase, "from the cedar to the hyssop," appears to be a direct reference to Hughes, who wrote indulgently about the joys of discovering the "Secrets" of earth's "Vegetable Creation," "from the lofty Cedar to the humble Hyssop" (Hughes 1750:iv and 293). Although these British naturalists had a particular skill with their "systematical arrangement" of West Indian plants and animals, it is to be regretted, Edwards argued, that they have "piled folio upon folio" and "made little proficiency in more popular, though perhaps not less useful, learning." He went on to say that all of the most well-known naturalists were "equally unpracticed and uninformed" in "commercial and political investigation." Edwards's critiques were shared by other writers, who also lamented that natural history obscured more "popular" topics (Anonymous 1796-1800:3-5). Nonetheless, they were too confrontational to make it into the final version of his preface. He completely removed his criticisms of natural history from the draft.

Although he does not acknowledge this, Edwards had another reason for being critical of natural history's practitioners. As the literary scholar Christopher P. Iannini has argued, "natural history is the eighteenth-century literary genre ... most directly engaged with the problem of slavery" (Iannini 2012:40). 
Because practitioners were typically visitors to the West Indies, as opposed to residents, they were more willing to document the brutal nature of colonial slavery. Importantly, they did not always intend to undermine planter culture in the process. Many of them seemed to agree with Hughes, who wrote that "As to the Slavery of these African Negroes, this Hardship is not so unsupportable to them; for they are very little better than Slaves in their own Country" (Hughes 1750:17). And yet, this sympathy for the worldview of colonial enslavers did not stop natural historians from commenting on the violence that they witnessed in the colonies. Despite this proslavery rhetoric, Hughes acknowledged "the hard labour, and often the want of necessaries, which these unhappy creatures are obliged to undergo," and how this treatment by white people destroyed "a greater number than are bred up here" (Hughes 1750:17). It was precisely these types of comments that antislavery agitators had started selectively excerpting by Edwards's time. The Quaker Anthony Benezet quoted this line in a wellknown polemical work called Some Historical Account of Guinea (Benezet 1771). By 1788, this work had become a favorite tool of the recently established London abolitionist society. ${ }^{21}$

Antislavery critics, such as Benezet and Sharp, made strategic use of natural histories. As Edwards knew well, these antislavery authors had also never been to the West Indies. And so, when Edwards critiqued natural historians as "equally unpracticed and uninformed," he was attacking their texts not only as natural histories, but also as sources of information for the abolitionists more generally (Dumas 2016:116). The case can be demonstrated most clearly with Hans Sloane and his Natural History of Jamaica. Crucially, although Sloane had spent fifteen months in the West Indies during the 168os, he was viewed by authors such as Long and Edwards as an outsider, another metropolitan chronicler who lacked "real" knowledge of the colonies. Part of this might have to do with the fact that Sloane had become a member of the Royal Society in 1685, before he ever went to the West Indies. By the time that Long and Edwards were writing, he had risen to become the epitome of elite British gentlemanly culture. He had served as secretary and president of the Royal Society, and his collections had formed the foundation of the British Museum. His outsider status, in the eyes of colonial historians, was also shaped by their perception that he had only "visited" the colonies. He had not lived there as a planter.

Most importantly, colonial historians cast Sloane as an outsider because he had revealed the horrors of plantation slavery. Sloane wrote in his introduc-

21 Granville Sharp to the Pennsylvania Society for Promoting the Abolition of Slavery, February 28, 1788. Historical Society of Pennsylvania, Pennsylvania Abolition Society Papers, Collection 049o, Series 2: Incoming Correspondence 1784-1795, Box 14, Folders 1-12. 
tion about the barbarous ways that Jamaican planters could legally torture their enslaved laborers. He described, for example, how enslaved people could be nailed to the ground with iron stakes; burned alive with hot brands; or have their feet chopped off with an ax (Sloane 1707, vol. 1:57). Antislavery writers mined Sloane's text for evidence that British slaveowners were savage, violent, and backward. Sloane's work became so effective as a tool for documenting slaveowner abuse that nearly all the most prominent antislavery authors decided to cite it in their published works. Benezet, Sharp, John Wesley, and Thomas Clarkson all drew upon Sloane's description of Jamaican slave laws to demonstrate the vicious nature of white planters. ${ }^{22}$ It is no wonder that West Indian colonists such as Long impugned Sloane's text as unreliable and full of "many errors" (Long 1774, vol. 2:134-36).

\section{$4 \quad$ The Insults of Colonial Degeneracy}

As Edwards was aware, many practitioners of natural history were also adherents of colonial degeneracy. Put simply, this was a theory that suggested that people who came from a tropical climate-mainly referring to people who were born in the tropics but also those who immigrated there-were biologically inferior to people from mainland Europe (Gerbi 1973). As a colonist himself, Edwards viewed this theory as being personally threatening to his legitimacy. He described it in his own words a couple of times throughout the draft, calling it, at one point, the idea "that the air and climate, or other physical phenomena in America, retard the growth of animated nature." In both his draft and final preface, Edwards mentioned this theory as being "the speculations of Mons. Buffon and some other French theorists, on the condition and character of the American nations." He was referring, of course, to the voluminous Histoire Naturelle by the French naturalist Georges-Louis Leclerc, as well as other French studies that followed his lead, particularly Cornelius Franciscus de Pauw's Recherches Philisophiques sur les Americains and Voyage à la Martinique by the colonial writer from Martinique, Jean-Baptise Thibault de Chanvalon (Leclerc 1749-1788; De Pauw 1773; de Chanvalon 1763).

The connection between natural history and colonial degeneracy can be understood by a discussion of Guillaume Thomas Raynal, better known as the Abbé Raynal, and his classic work, A Philosophical and Political History of the

22 Philmore 176o:48; Benezet 1762:53-55; Sharp 1769:64-65; Wesley 1774:25; and Clarkson 1786:xv. 
Settlements and Trade of the Europeans in the East and West Indies (Thomson 2017). First published as four volumes in French in 1770, the work went through several editions in Raynal's lifetime, and it became "the best known work of the French enlightenment in England" (Anstey 1975:123; Sypher 1942:96). Raynal and his contributors saw the Americas as being inferior to Europe, writing that "Nature seems to have strangely neglected the new world" (Dugatkin 2009:41). For Raynal, evidence of this inferiority could be found in both the natural and the social world. In addition to believing that the flora and fauna of the Americas were inferior-smaller and also fewer in number-Raynal believed that the climate of the Americas transformed Europeans into savages. He deplored planters' treatment of their enslaved laborers, viewing it as further evidence of this savage nature, and he famously encouraged slave insurrection with the words "Ou est-il çe nouveau Spartacus?" (Sypher 1942:96). Raynal's view of the planters as being "Savage Europeans!" was a common one during the period of abolition. It was articulated perhaps most famously in James Gillray's political cartoon Barbarities in the West Indies (Gillray 1791; Burnard \& Garrigus 2016:215).

Just as the Abbé Raynal made use of the science of natural history to criticize colonists, West Indian planters chose to attack Raynal's book by critiquing it as a work of natural history. In a manuscript treatise on race, the rector of St. Catherine's Parish in Jamaica, named John Lindsay, argued that Raynal could not be "trusted" as a source on the West Indies. For evidence, Lindsay cited Raynal's descriptions of natural phenomena, such as the "Cocoa" and the "Nut Meg Tree." He gave a detailed breakdown of why the descriptions were "false" and "incorrect," concluding that Raynal failed as a natural historian. He then connected these failings to his antislavery and antiplanter views. Raynal "seems to me," he argued, "as crude, as unconnected, and erroneous in his political principles, as in his botanic descriptions." ${ }^{23}$ This example helps us to see how natural history became a context for arguments about planter morality.

Despite these general critiques of those who advocated the theory of colonial degeneracy, Edwards reserved most of his criticisms for the Scottish historian William Robertson. Robertson was one of the most famous historians of the period. He was a cofounding member of the Royal Society of Edinburgh, principal of the University of Edinburgh, and the Royal historiographer of Scotland. Most importantly, he was an antislavery author and the most recent scholar to attempt a history of the West Indies, with his publication in 1777 of a two-volume work that was entitled The History of America. As Edwards

23 John Lindsay, A Few Conjectural Considerations upon the Creation of the Human Race, in C.E. Long Papers, BL, Add. MS 12439 , fols. $18^{\mathrm{v}}-23^{\mathrm{r}}$. This unpublished manuscript is dated July 23, 1788 from St. Jago de la Vega, Jamaica. 
knew, even though Robertson's work covered only the European discovery of the New World and the progress of Spanish colonization there, Robertson was currently working on more volumes that would address Britain's history in the West Indies. Edwards was disturbed by Robertson's embrace of colonial degeneracy in his first two volumes, and he was determined to write an indictment of that text in his preface. Of course, he could not have known that Robertson would die only a few days after Edwards published his History, without having produced any of his additional volumes on the British West Indies (Smitten 2017).

By his own account, Edwards's encounter with Robertson's The History of America completely changed the structure of his History. Instead of jumping immediately into a description of the British colonies, Edwards decided to open his work with "a retrospective survey of the state and condition of the West Indian Islands when first discovered by Columbus" (Edwards 1793, vol. 1:1-116). He surveyed accounts that related to "the condition, customs, manners, and genius of the antient inhabitants" in order to refute Robertson's argument "that Nature has regulated the genius of men by the degrees of latitude in which she has placed them." This process led Edwards into what can only be described as an antiracist defense of Native Americans as a people who were as diverse as any others on earth. Looked at more closely, however, Edwards's switching between "American Indians" or "American tribes" and the more generalized "American character" and "American species" reveals that he was simultaneously engaged in defending the white colonists or creole planters through a circuitous route.

Edwards's criticisms of Robertson were in service of his overall thesis that texts about the West Indies, written by metropolitan authors who had not visited or lived in the colonies, should be dismissed as unreliable works of scholarship. This was a common tactic among antiabolitionist writers, who frequently responded to their critics by attacking their research methods and their evidentiary support (Dumas 2016:122-26). In writing about Sloane, Long claimed that he "was obliged to rely chiefly on the writings and informations of other men, for want of opportunity to ground his descriptions on the result of his own personal experience" (Long 1774, vol. 2:136). Edwards dismissed Robertson in a similar style, writing that "Unless he himself visited the countries of which he writes, and had the benefit of actual experience and personal observation, neither genius nor Industry can at all times enable him to guard against the mistakes and misrepresentations of prejudiced, ignorant, or interested men" (Edwards 1793, vol. 1:vii). Although Edwards kept almost all of this criticism in his final draft, he softened it by editing out Robertson's name from the body of the text and leaving it only in the footnotes. 
Behind the scandalous observations of slavery that were printed in natural histories, and the insulting rhetoric of colonial degeneracy, was the material threat of abolition. Far and away, the longest section of material that Edwards wrote for his draft, and then entirely cut, related to this topic. Specifically, it was occasioned by the work of his "close friend" Edward Long. Generally, it related to Britain's antislavery movement. As historians have shown, Long's The History of Jamaica was one of the first texts to publicly defend colonial planters against criticisms of the growing antislavery movement. This work signaled a new era in the writing of West Indian history (Goveia 1956:173). It was published in the year 1774, at a time when a new and influential generation of antislavery texts, by authors such as Benezet and Sharp, were attacking the transatlantic slave trade and the institution of colonial slavery in the overseas territories. Equally important was the antislavery verdict of Somerset $v$. Stewart, which in 1772 had undermined slavery by declaring that it was incompatible with existing English law. It was in this era of the early 1770 s that planters in the British Empire came to the collective defense of slavery for the first time (C. Brown 2006:40-41; Swaminathan 2009:130).

To defend slavery, Long utilized "every available proslavery argument" and, in the process, turned The History of Jamaica into the "most exhaustive defence of colonial slavery ever written" (Wood 2002:142-43; Dumas 2016:77). Edwards utilized many of the same arguments throughout his career as a public defender of slavery. Some of them, like the idea that contemporary planters were not to blame for colonial slavery because they had only acquired their enslaved property by inheritance, he repeated in this draft (Long 1774, vol. 2:267; Edwards 1793, vol. 2:137). However, Edwards felt uncomfortable with particular lines of argumentation that Long had deployed in his History. One of these-a racist argument about the inherent inferiority of Africans and people of African descent_-Edwards decided to address openly in his draft (Long 1774, vol. 2:35183 ; C. Hall 2016). His effort to defend Africans as a race of people was consistent with his attempt to defend Native Americans in opposition to Robertson's work on colonial degeneracy.

Before we discuss Edwards's engagement with Long's History, in the context of his early draft, it would be helpful to provide a bit of background on their relationship. The two historians emigrated to Jamaica in the late 175 os and then entered the colonial assembly in the early 176 os. They knew each other by at least 1765 , when they served on the same committee to investigate the origins of a slave conspiracy in St. Mary's Parish (Aikman 1811-1829, vol. 5:556, 591-96). From this point on, they would serve on committees together for the rest of 
their lives. As previously mentioned, both were regular participants of the Society of West India Planters and Merchants, in which forum they met throughout the 1770 s, 178 os, and 179 os. $^{24}$ Nine years older than Edwards, Long was considered by him to be more than a friend. He was also an advisor. Edwards praised Long's History, calling it "a book which is written on so enlarged and liberal a scale" and is so "fraught with such deep and solid reflections." He claimed that, if Long had covered the rest of the West Indies, instead of only Jamaica, then there would have been no need for his own work. In particular, Edwards admired Long's History because it broke away from the genre of natural history. Even though Long had cataloged natural phenomena in his third volume, he had also devoted more attention to Jamaica's enslaved population in his second volume than any British historian before his time (Long 1774, vol. 2:26o-505).

Even though Edwards was excited by the increased attention that Long gave to Africans in the West Indies, he did not agree with the way that Long covered the topic. ${ }^{25}$ Long was among a group of white intellectuals who responded to emerging challenges to racialized slavery in the late-eighteenth century by espousing a discourse of savagery and racism (Hume 1753; Jefferson 1787; Romans 1775). Yet, even among this generation, Long exhibited a degree of racism that was blatant. He exhibited this racism most explicitly in The History of Jamaica. He wrote, for instance, that all black people were "void of genius" and incapable of the "mechanic arts," that they were generally "more inclined to a life of idleness and ease, than a life of labour," and that they were, biologically, more related to certain animals than they were to white people (Long 1774, vol. 2:351-83, 475-85). Although Long wrote about the African continent at length, he was not above making racist generalizations like this one: the various regions are "occupied by petty Negroe states, whose character is nearly uniform, and who scarcely deserve to be ranked with the human species" (Long 1774, vol. 2:373). Long was recognized as what we would today call racist by certain writers of his own time, who singled out this sort of evidence from The History of Jamaica in their criticisms (Ramsay 1784:132,197-98; Wilberforce 1807:56-61).

In writing his draft, Edwards tried to distance himself from his mentor's racist views. He began by praising Long's example, and then he clarified that "I dare not therefore suffer my esteem for my friend to suppress my opinion,

24 Minutes of the Society of West India Planters and Merchants, $1785^{-1792}$, Alma Jordan Library, University of the West Indies, St. Augustine, Trinidad, SC 89, Box 2, Folder 4, 31-32; and 1793-1801, sc 89, Box 2, Folder 5, 10-11.

25 Marginal Notes to Edward Long's The History of Jamaica, the West Indies Special Collection, Mona Library, Jamaica, F1868.L84. 
when I find myself impelled to dissent from him on questions of importance." Foremost among these "questions of importance" were the issues of slavery and race; or, in his own language, "the subject of the slavery of the Negroes, and on the character and genius of that unhappy race of people." Edwards claimed that, in comparison to Long, he wanted to vindicate the African race and also to "offer the best practical remedy" to the "abuses and evils" of the practice of colonial slavery. Before going further, it should be clarified that, despite this posturing, Edwards was no less of a slaveowner than Long. At the time of these statements, he held no fewer than 6oo black people in bondage in Jamaica. ${ }^{26}$ Nonetheless, as previously stated, Edwards defended colonial slavery in a style very different from that of Long. Instead of using a discourse of racism and savagery, he used a discourse of rationalism, humanity, moderation, and amelioration (Davis 1975:188-89; Petley 2018:193-95). In summary, he can be said to have defended the sinner while deploring the sin at the same time. This worldview is captured by an oft-quoted line that Edwards repeated in some of his published work: "Nothing is more certain," Edwards wrote, "than that the Slave Trade may be very wicked, and the planters in general very innocent" (Edwards 1793, vol. 2:236; Edwards 1789:13-14).

We have already seen how Edwards argued for his credibility over Robertson's on the basis of his personal history in the West Indies. Of course, Edwards could not make this same argument for himself relative to Edward Long, who had also resided in the Caribbean. Instead, Edwards justified his authority over Long, to himself, on the basis of superior research methods in Britain. Evidence for this can be found in his marginal annotations to Long's History. In these annotations, Edwards frequently criticized Long for his supposed failure to have studied sources in the Spanish language. For example, Long wrote that Port Maria, on the north side of Jamaica, was well known for giving "an asylum to Columbus, when his ship was near foundering with a leak" (Long 1774, vol. 2:75). Edwards replied, "This was never supposed by anyone that ever read Herrera or the other Spanish Historians." Similarly, when Long wrote that Spaniards in Jamaica had obtained their sugarcane plants from "the Brasils," Edwards responded that this is "a strange mistake which a very slight acquaintance with Herrera-Oviedo or any of the ancient Spanish writers would have corrected."27 In these moments, we see that Edwards was using small issues as a way to build up his confidence and rationalize his right to refute Long on greater issues like slavery.

26 "Will of Bryan Edwards of Polygon, Southampton, Hampshire," тNA Р Rов 11/1346/85.

27 Bryan Edwards, Marginal Notes to Edward Long's The History of Jamaica, the West Indies Special Collection, Mona Library, Jamaica, F1868.L84, vol. 2:75, vol. 1:343 and 435. 
Edwards did not enter into an exegetical criticism of Long's History, like he did for Robertson's The History of America. Instead, he went on what he called a "digression" about the failings of the planters generally in the face of critique. "It appears to me," he wrote,

that our Planters have adopted a line of conduct, which, instead of removing the public odium from themselves, and directing it to its proper object, has served rather to confirm the popular prejudice that most falsely and cruelly arraigns them as the sole authors and supporters of the slave-trade in our Islands ... Instead of retiring to a citadel within their reach, they have endeavoured to maintain a distant out-post, with which, in sound policy, they have no concern, which in fact is not tenable, and which it is their interest to desert.

Edwards's draft preface, vi-vii

In this quote, Edwards criticized his peers for failing to properly respond to abolitionist critiques. Their main failure was in not redirecting this criticism "to its proper object" and in not "retiring to a citadel within their reach." On the next page, Edwards explained in no uncertain terms what he meant by his use of these phrases. In what can be considered his thesis statement, he declared, "it is not by the inhabitants of the Colonies the slave-trade is carried on, but by the Merchants of this kingdom; and it is the Government of Great Britain that protects and supports it."

Of course, Edwards was not the first author who tried to shift the blame away from West Indian planters and on to other shareholders of Britain's transatlantic slave trade. The Nevis clergyman Robert Robertson had done this in a series of proslavery texts he wrote in the 1730 and 1740 (R. Robertson 1730; C. Brown 2006:33-36). Perhaps most famously, the Virginian slaveowner Thomas Jefferson had tried to place the blame for the institution of slavery in the United States on King George III in an earlier draft of The Declaration of Independence (Davis 1975:173). That being said, Edwards had, with a remarkable degree of consistency, represented British merchants as the "true" agents of the transatlantic slave trade since the 1770 . He had waxed eloquently about the horrors of the slave trade in his private notes on Long's History. In two earlier anti-abolitionist pamphlets that he wrote from Jamaica-called Two Reports and A Speech Delivered at a Free Conference - he even sided with the abolitionists on questions of overseeing the slave trade, saying that government regulations, such as the 1788 Dolben's Bill, were "founded in justice, humanity, and necessity" (Jamaican Assembly 1789:2 and 16; Logerfo, 1973). In these two writings, Edwards had tested out his tactic of defending the West Indian 
planters by redirecting blame to the British merchants in the slave trade. In his draft, he tried to advance this idea even further by referencing evidence that he had not previously shared in any of his published work.

As proof of his argument that British slave traders, as opposed to West Indian slaveowners, were really the ones to blame for the horrors of the slave trade, Edwards cited an event that took place in the year 1774. He writes that the Jamaican legislature had passed a bill to prohibit the importation of older Africans by placing an import duty on those above the age of thirty. ${ }^{28}$ The governor gave his assent to this law, according to Edwards, because older Africans had acquired a reputation for instigating slave revolts, and because the early $1770 s$ had seen an "excessive importation." ${ }^{29}$ And yet, when the bill arrived in England for confirmation by the Crown, it was fiercely resisted by the slave merchants of Liverpool, who convinced the Board of Trade to bury the measure. To Edwards, this event was a practical example of how slave traders could use the metropolitan government to usurp the authority of local colonial legislatures and, thus, determine the laws of West Indian societies. Jefferson had referenced similar problems in his draft of the Declaration, accusing the Crown of "suppressing every legislative attempt to prohibit or to restrain" the transatlantic slave trade by "prostituting his negative." This history was not lost on Edwards. In his draft, he made an explicit reference to the inability of the North American colonies to legislate against the transatlantic slave trade in the years leading up to the American Revolution (Wolf 2006:22-27).

As scholars have argued, Edwards often appropriated the language of antislavery. He turned "the sentimental rhetoric of the abolitionists" against the antislavery movement (Bird 2007:27-46; Scott 2008:12-31). One example of this appears in a paragraph that he later deleted from his preface, in which he tried to argue that not every planter in the West Indies is a "remorseless tyrant." He related a story about a time that he supposedly redeemed a crew of itinerant enslaved workers, known in Jamaica as jobbers (Radburn \& Roberts 2019). As peripatetic laborers, hired-out to planters who wanted to lighten the burdens of their resident enslaved populations in particular seasons, jobbers worked under some of the most violent conditions. In this story, Edwards claimed that he rescued these jobbers by purchasing and then resettling them into families

28 The law was "An Act for Laying an Additional Duty on all Negroes Imported into this Island." For records of this law in the colonial legislature, see Aikman 1811-1829, 6:507-8. It passed by a margin of 16 to 4 votes on February 12, 1774. For records of this law's hearing in England, see the Journal of the Commissioners for Trade and Plantations, Volume 13, January of 1768 to December of 1775, London: Public Record Office, 1937, 401-17.

For the growth of slave importation to the island in the early 1770s, see Diptee 2012:139. 
on his own properties, giving them lands and treating them fairly. In a transparent appeal to the reader's sympathy, he confessed that he "never felt such genuine satisfaction" in his life than when he "visited them afterwards" in their homes. "They never failed to come to me," he stated, "with their wives and little ones-all laden with presents of fruit and poultry, which they laid at my feet; and, embracing them with tears of affection and gratitude, exhibited a scene that would have warmed the coldest bosom." Unlike certain public statements that Edwards later gave to defend his History, perhaps he felt that this story was too transparent of an appeal to remain in his final draft. ${ }^{30}$

In the end, Edwards removed all of his critiques of the transatlantic slave trade, as well as his critiques of Edward Long. It seems obvious, in retrospect, that the primary reason he had sent his draft preface to Long was to get his blessing on the section that he composed in criticism of him. In both the tone and language of his letter, it is clear that Edwards knew he was potentially overstepping his boundaries. He told Long to "be not alarmed" because, although "I have taken great liberty with your name," "the whole may be suppressed if you think I have dealt too hardly by you." He pretended to be defiant, saying that "less cannot, and shall not" be said on this subject. Of course, this proved to be a case of false courage. Edwards then resorted to standard and polite affectations, telling Long to present his compliments to his wife and family. He concluded the letter with a postscript that is little more than a shameless and transparent attempt to salvage Long's goodwill by appealing to one of their mutual critics. "Tell me what you think," he wrote, "of my critical castigation of Dr. Robertson.- I have a very serious expostulation with him in the body of my work." Knowing that Robertson condescended to the "American character" with his ideas of colonial degeneracy, and adhered to antislavery views that were based in the practice of natural history, this postscript was a safe appeal to make (W. Robertson 1759:32).

We have no record of Long's reply to Edwards's letter and draft. If the total omission of all criticisms of Long in the final preface can stand on its own as evidence, then it is obvious that Long did not approve of Edwards's attempt to establish his scholarly reputation against his own name. On a more general note, it is obvious that Long disagreed with Edwards about the "proper object" of proslavery criticism and that "citadel within their reach." In fact, Long had been working intimately for the past five years with the slave traders of Liver-

30 For a very similar example of Edwards using sentimentalism in the form of a personal story, see his response to the Irish poet William Preston's critiques of his History in Monthly Review, September and October 1795, no. 18, pp. 238-40. Edwards was responding to Preston's A Letter to Bryan Edwards (Preston 1795). 


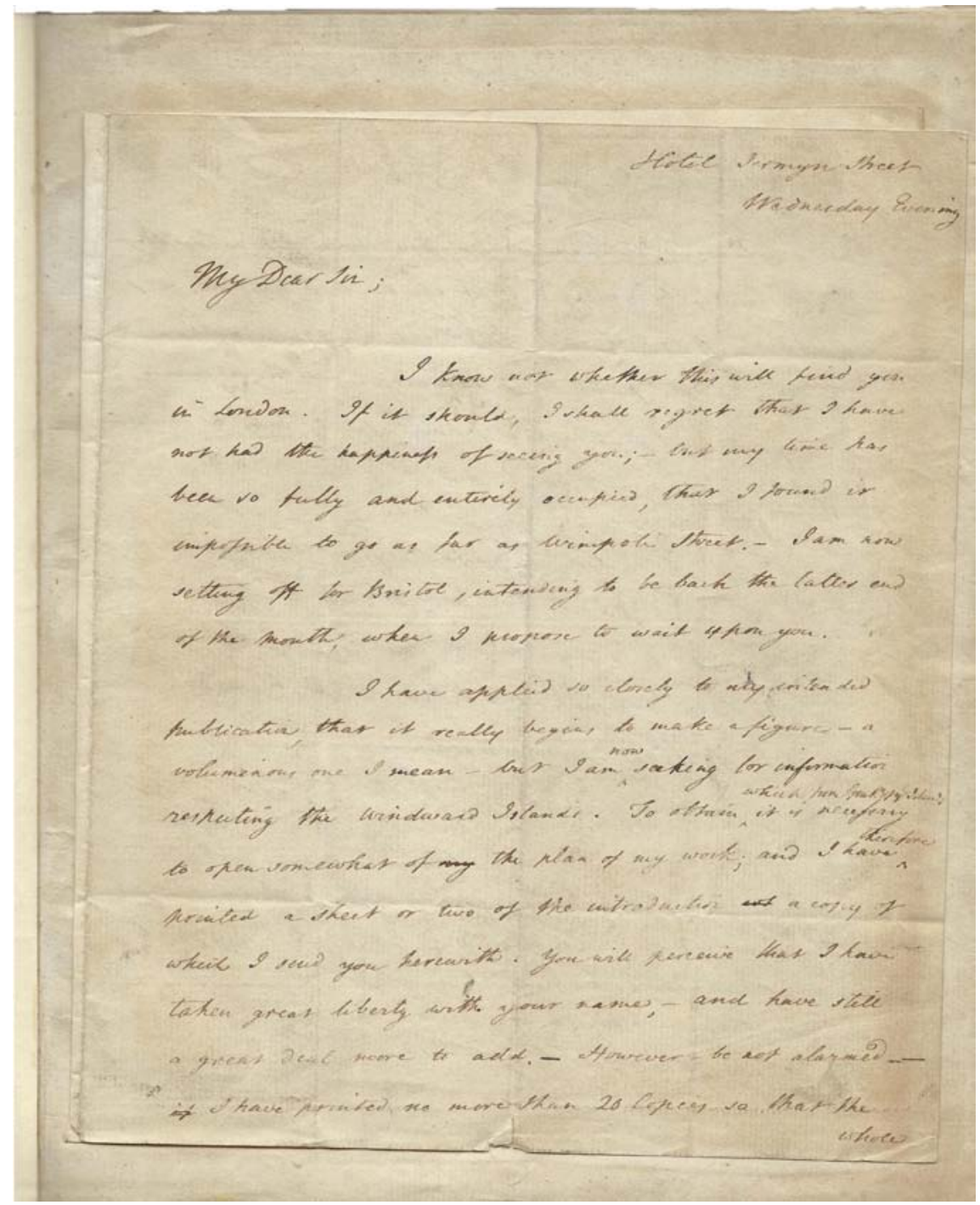

FIGURES 5-6 First and second page of Edwards's letter to Long

The draft of Edwards's preface that survives was enclosed in a letter to his friend, the planter and historian Edward Long. Edwards used his draft to critique Long's views on slavery and race. He sent Long his preface to get an idea for how Long would receive these critiques. Letter of Bryan Edwards to Edward Long, ca. 1792, exact date unknown, ICs 96, 3, 4, the West India Committee, Westminster.

(C) THE WEST INDiA COMMITTEE (ICS 96, 3, 4) 


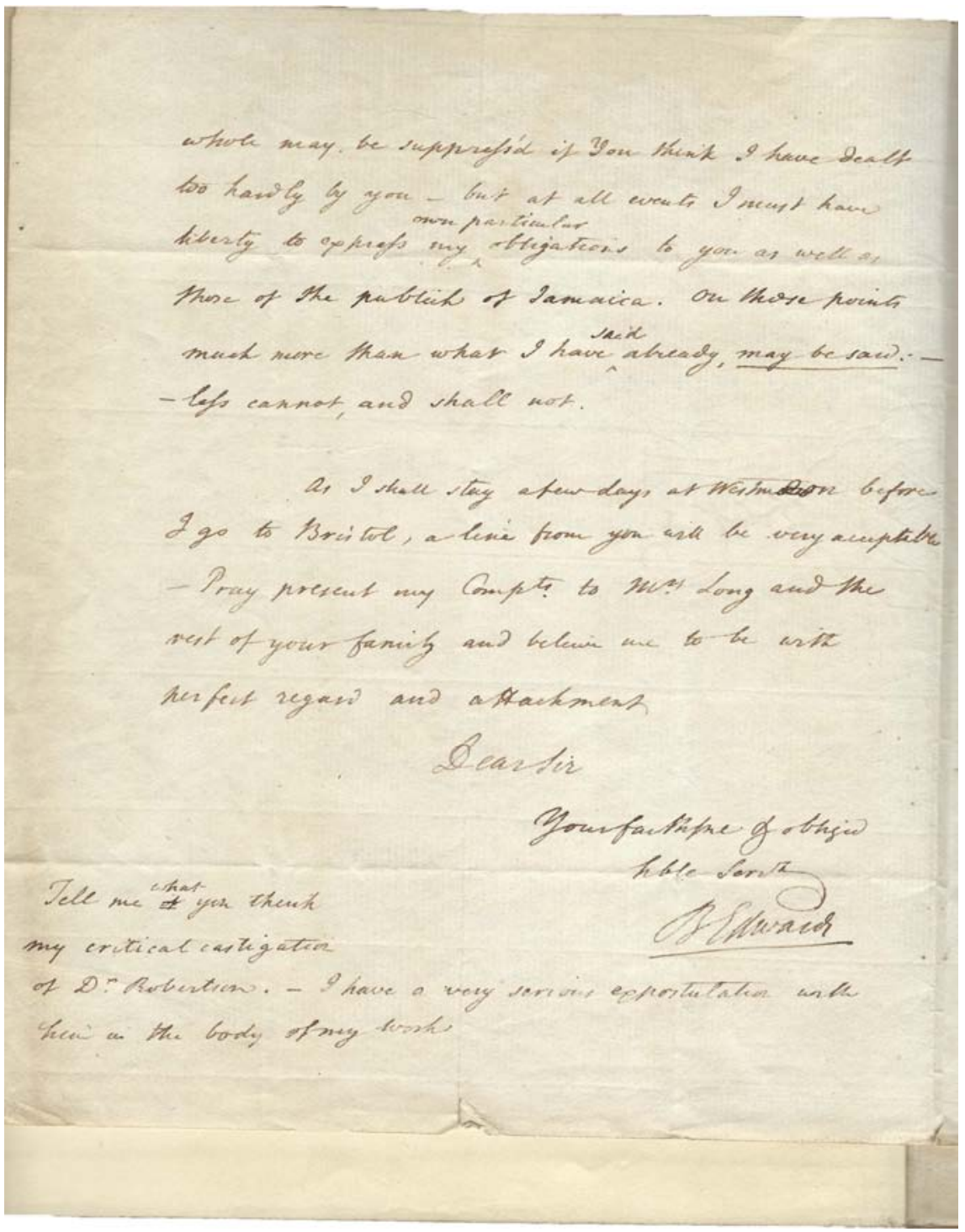


pool, the exact people whom Edwards was indicting, to oppose the abolitionist movement (Norris 1789; Goveia 1956:61). All of the evidence suggests that Long believed, in contrast to Edwards, that the fates of British slave traders and West Indian slaveowners were tightly bound. The anti-abolitionist Stephen Fuller had earlier warned Edwards about his public criticisms of British slave merchants. ${ }^{31}$ In all likelihood, Long said something similar in a response. Regardless, Edwards's attempt to rebuke his mentor's position on race and slavery did not come at the cost of their friendship. It appears that Edwards and Long remained friends for the remainder of Edwards's life.

Why did Edwards edit these criticisms out of his first draft? As Keith Thomas has argued in his book, In Pursuit of Civility, British gentlemen in the eighteenth century judged one another as "civilized" according to such qualities as "politeness" and "agreeableness" (Thomas 2018:xv). Others, such as Anthony Barker in The African Link, have demonstrated how eighteenth-century authors would sometimes go to great lengths to avoid openly criticizing their opponents' views. In one case, they went so far as to refer to Long's racist work anonymously, as if there had been "a conspiracy of silence" (Barker 1978:12). There is, in one of Long's earlier fictional writings, a relevant insight into this British gentlemanly culture. Long's narrator, a man named Nicholas Babble, received some sage advice from a "very honest" neighbor. The neighbor suggested that Babble take up a job as a contributor to a weekly newspaper:

He thought I might manage a Paper once a week with spirit, and please the Public in the character of an Author, provided I took care not to deal too much in tittle tattle. He advised me at the same time to write in such a manner as to give offence to no party whatever. 'Be particularly careful, Friend Nicholas,' said he, 'to avoid all personal reflections. You had far better be dull than abusive; and be called a stupid fellow, than a scurrilous one. If you discover a disposition to give pleasure, and to gain every body's good will, you will be received with candour; but a snarler, take my word for it, can be agreeable to no body'.

LONG 1757:3-4

Perhaps Long gave Edwards similar advice as that of Babble's neighbor. In the end, Edwards may not have succeeded at the task of giving "offence to no part

31 See Stephen Fuller to Bryan Edwards, March 3, 179o, Duke University, David M. Rubenstein Rare Book \& Manuscript Library, The Correspondence of Stephen Fuller, MS 5642, pp. $480-81$. 
whatever," though he was definitely much less of a "scurrilous" "snarler" than in his first draft. He was amply rewarded for it as well. As previously mentioned, his History earned him a nomination to the Royal Society. It is difficult to imagine that nomination coming if Edwards had retained his criticisms of Sloane, a former president of the Society. Equally, perhaps Edwards was grateful that he cut Robertson's name from the body of the preface, seeing as the author passed away unexpectedly.

\section{Conclusion}

Overall, the picture that we get from reading this early draft of Bryan Edwards's preface to his History is that of an emerging scholar, struggling to defend West Indian planters while establishing an identity for himself apart from his mentor. We see a colonial intellectual, who is responding to the challenges of his day by attempting to seize the narrative of West Indian history from the pens of metropolitan authors. By far, the most notable characteristic of Edwards's draft is its explicit hostility to West Indian writing as it existed at the time. Edwards impugned natural history, going so far as to insult practitioners such as Sloane, a man who was revered in Britain for his contributions to science and the founding of the British Museum (Delbourgo 2017). He assailed metropolitan authors like Robertson, who had long dominated the production of West Indian scholarship from their armchairs in Europe, as having disqualified themselves by their physical distance from the colonies. Most surprisingly, he turned against fellow enslavers such as Long, who had relied on racism in order to justify the transatlantic slave trade.

Taken together, these criticisms show us that Edwards envisioned a history of the British West Indies that was more focused on what we might today call "social" instead of "natural" history; that was written by people who had actually resided in the islands; and that was at least relatively antiracist. Of course, Edwards failed to achieve this history. He removed his critiques of natural history and of his racist peers, and he softened his attacks on metropoli$\tan$ authors. These compromises remind us of the social pressures that were very much a part of British gentlemanly culture in the late eighteenth century. Works on the British West Indies would not become all of the things that Edwards claimed to desire within his own lifetime. Instead, these changes would have to wait until the modern era. 


\section{Acknowledgements}

The author would like to thank the following people and institutions: Josh Piker, John Smolenski, Trevor Burnard, David Wells, Blondel Cluff, Barnabas Kinge, Charlie Wheeler, Rosemarijn Hoefte, Sandra Powlette, Jonathon Vines, Gina Rozario, Samuel Conrad Scott, Michael Becker, Jeremy Till, Kathryn ReedSmith, Sean Gallagher, the Uc Davis History Department, uc Davis Graduate Studies, and the staff of the West India Committee, the British Library, the Mona Library, the Jamaica Archives and Records Department, the Institute for Commonwealth Studies, and the National Portrait Gallery. Finally, the author would like to thank the staff and anonymous reviewers of New West Indian Guide/Nieuwe West-Indische Gids.

\section{References}

Aikman, Alexander (ed.), 1811-1829. Journals of the Assembly of Jamaica, 1663-1826. 14 vols. St. Jago de la Vega, Jamaica: Jamaican Assembly.

Anonymous, 1797. Introduction to "Characteristic Traits of the Creolian and African Negroes in this Island, \&c. \&c." In William Smart (ed.), The Columbian Magazine; or Monthly Miscellany. Kingston: William Smart, pp. 3-8.

Anstey, Roger, 1975. The Atlantic Slave Trade and British Abolition, 1760-1810. London: MacMillan.

Bauer, Ralph, 2003. The Cultural Geography of Colonial American Literatures: Empire, Travel, Modernity. Cambridge: Cambridge University Press.

Barker, Anthony J., 1978. The African Link: British Attitudes to the Negro in the Era of the Atlantic Slave Trade, 1550-1807. London: Frank Cass.

Benezet, Anthony, 1762. A Short Account of that Part of Africa Inhabited by the Negroes. Philadelphia: W. Dunlap.

Benezet, Anthony, 1771. Some Historical Account of Guinea: Its Situation, Produce, and the General Disposition of Its Inhabitants. Philadelphia: Joseph Crukshank.

Bird, Robert Braxton, 2007. 18th Century Transformations of the Jamaican Plantocracy: Edward Long and Bryan Edwards. MA Thesis, Florida State University, Tallahassee.

Blome, Richard, 1672. A Description of the Island of Jamaica: With the Other Isles and Territories in America, to Which the English Are Related. London: E. Milbourn.

Blouet, Olwyn M., 20oo. Bryan Edwards, F.R.S., 1743-1800. Notes and Records of the Royal Society of London 54(2):215-22.

Blouet, Olwyn M., 20o1. Bryan Edwards and the Haitian Revolution. In David P. Geggus (ed.), The Impact of the Haitian Revolution in the Atlantic World. Columbia: University of South Carolina Press, pp. 44-57. 
Board of Trade, 1937. Journal of the Commissioners for Trade and Plantations, Volume 13, January 1768-December 1775. London: H.M. Stationery Office.

Boulukos, George E., 2008. The Grateful Slave: The Emergence of Race in EighteenthCentury British and American Culture. Cambridge: Cambridge University Press.

Boyle, Robert, 1665. General Heads for a Natural History of a Countrey, Great or Small, Imparted Likewise by Mr. Boyle. Philosophical Transactions of the Royal Society of London 1(11):186-89.

Brading, David, 1991. The First America: The Spanish Monarchy, Creole Patriots, and the Liberal State, 1492-1866. Cambridge: Cambridge University Press.

Brown, Christopher Leslie, 2006. Moral Capital: Foundations of British Abolitionism. Chapel Hill: University of North Carolina Press.

Brown, Vincent, 2020. Tacky's Revolt: The Story of an Atlantic Slave War. Cambridge MA: Harvard University Press, Belknap Press, 2020.

Browne, Patrick, 1756. The Civil and Natural History of Jamaica. London: Printed for the author.

Burke, Edmund, 1757. An Account of the European Settlements in America. 2 vols. London: J. Dodsley.

Burnard, Trevor, 2004. Mastery, Tyranny, and Desire: Thomas Thistlewood and His Slaves in the Anglo-Jamaican World. Chapel Hill: University of North Carolina Press.

Burnard, Trevor \& John Garrigus, 2016. The Plantation Machine: Atlantic Capitalism in French Saint-Domingue and British Jamaica. Philadelphia: University of Pennsylvania Press.

Burton, Robert, 1685. The English Empire in America; Or, a View of the Dominions of the Crown of England in the West-Indies. London: A. Bettesworth.

Cañizares-Esguerra, Jorge, 2001. How to Write the History of the New World: Histories, Epistemologies, and Identities in the Eighteenth-Century Atlantic World. Stanford CA: Stanford University Press.

Catesby, Mark, 1729-1747. Natural History of Carolina, Florida and the Bahama Islands Containing the Figures of Birds, Beasts, Fishes, Serpents, Insects and Plants. 2 vols. London: Printed for the author.

Clarke, Samuel, 1670. A True and Faithful Account of the Four Chiefest Plantations of the English in America. London: Robert Clavel et al.

Clarkson, Thomas, 1786. An Essay on the Slavery and Commerce of the Human Species. Philadelphia: Joseph Crukshank.

Craskell, Thomas, 1763. Map of the County of Surry in the Island of Jamaica. London: D. Fournier.

Cundall, Frank, 1915. Historic Jamaica. London: West India Committee.

Davis, David Brion, 1975. The Problem of Slavery in the Age of Revolution, 1770-1832. Ithaca, NY: Cornell University Press.

Dayan, Joan, 1995. Haiti, History, and the Gods. Berkeley: University of California Press. 
De Chanvalon, Jean-Baptiste Thibault, 1763. Voyage à la Martinique: Contenant Diverses Observations etc. Paris: J.B. Bauche.

Delbourgo, James, 2017. Collecting the World: Hans Sloane and the Origins of the British Museum. Cambridge MA: Harvard University Press, Belknap Press.

Diptee, Audra A., 2012. From Africa to Jamaica: The Making of an Atlantic Slave Society, 1775-1807. Gainesville: University Press of Florida.

Dugatkin, Lee Alan, 2009. Mr. Jefferson and the Giant Moose: Natural History in Early America. Chicago: University of Chicago Press.

Dumas, Paula E., 2016. Proslavery Britain: Fighting for Slavery in an Era of Abolition. London: Palgrave MacMillan.

Edwards, Bryan, 1789. A Speech Delivered at a Free Conference between the Honourable the Council and Assembly of Jamaica ... Kingston: Alexander Aikman.

Edwards, Bryan, 1793. The History, Civil and Commercial, of the British Colonies in the West Indies. 2 vols. London: John Stockdale.

Edwards, Bryan, 1794. A Map of the Island of Jamaica. London: John Stockdale.

Edwards, Bryan, 1801. The History, Civil and Commercial, of the British Colonies in the West Indies, Vol. 1. London: T. Miller.

Fabella, Yvonne, 2010. Redeeming the "Character of the Creoles": Whiteness, Gender, and Creolization in Pre-Revolutionary Saint Domingue. Journal of Historical Sociology $23(1): 40-72$.

Geggus, David P. (ed.), 2001. The Impact of the Haitian Revolution in the Atlantic World. Columbia: University of South Carolina Press.

Gerbi, Antonello, 1973. The Dispute of the New World: The History of a Polemic, 1750-1900. Trans. Jeremy Moyle. Pittsburgh: University of Pittsburgh Press.

Gillray, James, 1791. Barbarities in the West Indies. London: Hannah Humphrey.

Goveia, Elsa V., 1956. A Study on the Historiography of the British West Indies to the End of the Nineteenth Century. Mexico: Instituto Panamericano de Geografia e Historia.

Griffith, Ivelaw Lloyd, 1993. The Quest for Security in the Caribbean: Problems and Promises in Subordinate States. Armonk NY: M.E. Sharpe.

Hakewill, James, 1825. A Picturesque Tour of the Island of Jamaica: From Drawings Made in the Years 1820 and 1821. London: Hurst and Robinson.

Hall, Catherine, 2016. Whose Memories?: Edward Long and the Work of Re-Remembering. In Katie Donington, Ryan Hanley \& Jessica Moody (eds.), Britain's History and Memory of Transatlantic Slavery: Local Nuances of a "National Sin." Liverpool, U.K.: Liverpool University Press, pp. 129-48.

Hall, Douglas, 1971. A Brief History of the West India Committee. St. Lawrence, Barbados: Caribbean Universities Press.

Higman, Barry, 1999. Writing West Indian Histories. London: Macmillan Education.

Howard, Robert Mowbray (ed.), 1925. Records and Letters of the Family of the Longs of 
Longville, Jamaica, and Hampton Lodge, Surrey. 2 vols. London: Simpkin, Marshall, Hamilton, Kent \& Co.

Hughes, Griffith, 1750. The Natural History of Barbados: In Ten Books. London: Printed for the author.

Hume, David, 1753. Essays and Treatises on Several Subjects. London: A. Millar.

Iannini, Christopher P., 2012. Fatal Revolutions: Natural History, West Indian Slavery, and the Routes of American Literature. Chapel Hill: University of North Carolina Press.

Jamaican Assembly, 1789. Two Reports (One Presented the 16th of October, the Other on the 12th of November, 1788) from the Committee of the Honourable House of Assembly of Jamaica. London: B. White.

Jefferson, Thomas, 1787. Notes on the State of Virginia. London: John Stockdale.

Jefferys, Thomas, 1780. The West-India Atlas: or, A Compendious Description of the WestIndies. London: Robert Sayer and John Bennett.

Jordan, Winthrop D., 1968. White over Black: American Attitudes Toward the Negro, 15501812. Chapel Hill: University of North Carolina Press.

Leclerc, Georges-Louis [Comte de Buffon], 1749-1788. Histoire Naturelle, Générale et Particulière. 36 vols. Paris: L'Imprimerie Royale.

Lewis, Gordon, 200o. Pro-Slavery Ideology. In Verene Shepherd \& Hilary McD. Beckles (eds.), Caribbean Slavery in the Atlantic World: A Student Reader. Kingston: Ian Randle, pp. 544-79.

Lewis, Kay Wright, 2017. A Curse upon the Nation: Race, Freedom, and Extermination in America and the Atlantic World. Athens: University of Georgia Press.

Ligon, Richard, 1657. A True and Exact History of the Island of Barbados: Illustrated with a Map of the Island, as also the Principal Trees and Palms. London: Humphrey Moseley.

LoGerfo, James W., 1973. Sir William Dolben and "The Cause of Humanity": The Passage of the Slave Trade Regulation Act of 1788. Eighteenth-Century Studies 6(4):43151.

Long, Edward, 1757. The Prater: By Nicholas Babble, Esq. London: T. Lowndes.

Long, Edward, 1774. The History ofJamaica: Or, General Survey of the Antient and Modern State of that Island. 3 vols. London: T. Lowndes.

Moseley, Benjamin, 1799. A Treatise on Sugar: With Miscellaneous Medical Observations. London: John Nichols.

Newman, Brooke N., 2018. A Dark Inheritance: Blood, Race, and Sex in Colonial Jamaica. New Haven CT: Yale University Press.

Norris, Robert, 1789. Memoirs of the Reign of Bossa Ahádee, King of Dahomey, an Inland Country of Guiney. London: W. Lowndes.

Oldmixon, John, 1708. The British Empire in America. 2 vols. London: John Nicholson. 
O'Shaughnessy, Andrew J., 1997. The Formation of a Commercial Lobby: The West India Interest, British Colonial Policy, and the American Revolution. Historical Journal 4O(1):71-95.

Parrish, Susan Scott, 2006. American Curiosity: Cultures of Natural History in the Colonial British Atlantic World. Chapel Hill: University of North Carolina Press.

Pauw, Cornelius Franciscus de, 1773. Recherches Philisophiques sur les Americains. Paris: Jean-Francois Bastien.

Penson, Lillian M., 1921. The London West India Interest in the Eighteenth Century. English Historical Review 36(143):373-92.

Petley, Christer, 2012. Rethinking the Fall of the Planter Class. Atlantic Studies: Global Currents 9(1):1-17.

Petley, Christer, 2018. White Fury: A Jamaican Slaveowner and the Age of Revolution. Oxford: Oxford University Press.

Philmore, J., 176o. Two Dialogues on the Man-Trade. London: J. Waugh.

Poyer, John, 1808. The History of Barbados: From the First Discovery of the Island in the Year 1605, till the Accession of Lord Seaforth, 1801. London: J. Mawman.

Preston, William, 1795. A Letter to Bryan Edwards, Esquire, Containing Observations on Some Passages of His History of the West Indies. London: J. Johnson.

Price, Richard \& Sally Price (eds.), 1988. Narrative of a Five Years Expedition Against the Revolted Negroes of Surinam: Transcribed for the First Time from the Original $179^{\circ}$ Manuscript. Baltimore MD: Johns Hopkins University Press.

Price, Richard \& Sally Price (eds.), 1992. Stedman's Surinam: Life in an EighteenthCentury Slave Society. Baltimore MD: Johns Hopkins University Press.

Radburn, Nicholas \& Justin Roberts, 2019. Gold versus Life: Jobbing Gangs and British Caribbean Slavery. William and Mary Quarterly 76(2):223-56.

Ragatz, Lowell Joseph, 1928. The Fall of the Planter Class in the British Caribbean, 17631833: A Study in Social and Economic History. New York: Century Co.

Ragatz, Lowell Joseph \& Mary Parker Ragatz, 1932. A Guide for the Study of British Caribbean History, 1763-1834: Including the Abolition and Emancipation Movements. Washington DC: Government Printing Office.

Ramsay, James, 1784. An Essay on the Treatment and Conversion of African Slaves in the British Sugar Colonies. London: James Phillips.

Raynal, Abbé [Guillaume Thomas Raynal], 1777. A Philosophical and Political History of the Settlements and Trade of the Europeans in the East and West Indies. 5 vols. London: T. Cadell. [Orig. 1770.]

Robertson, Robert, 1730. A Letter to the Right Reverend the Lord Bishop of London, from an Inhabitant of His Majesty's Leeward-Caribbee-Islands. London: J. Wilford

Robertson, William, 1759. The Situation of the World at the Time of Christ's Appearance: And Its Connection with the Success of His Religion Considered. Edinburgh: Hamilton and Balfour. 
Robertson, William, 1777. The History of America. 2 vols. London: W. Strahan.

Romans, Bernard, 1775. A Concise Natural History of East and West Florida: Containing, an Account of the Natural Produce of All the Southern Part of British America. New York: Printed for the author.

Ryden, David Beck, 2009. West Indian Slavery and British Abolition, 1783-1807. Cambridge: Cambridge University Press.

Saxe, E.L., 1971. The Political Career of Bryan Edwards, 1765-180o. MA Thesis, City University of New York.

Scott, Samuel Conrad, 20o8. The Enlightenment of Bryan Edwards: Slavery, Fear, and Historical Writing in the Eighteenth-Century Atlantic. BA Thesis, Harvard University, Cambridge MA.

Sharp, Granville, 1769. A Representation of the Injustice and Dangerous Tendency of Tolerating Slavery. London: Benjamin White.

Sheridan, Richard B., 1974. Sugar and Slavery: An Economic History of the British West Indies, 1623-1775. Kingston: Canoe Press.

Sheridan, Richard B., 2004. Edwards, Bryan. Oxford Dictionary of National Biography. Oxford: Oxford University Press.

Sloane, Hans, 1707. A Voyage to the Islands Madera, Barbados, Nieves, S. Christophers and Jamaica: With the Natural History of the Herbs and Trees etc. 2 vols. London: Printed by B.M. for the author.

Smith, William, 1745. A Natural History of Nevis, and the Rest of the English Leeward Charibee Islands in America. London: J. Bentham.

Smitten, Jeffrey R., 2017. The Life of William Robertson: Minister, Historian, and Principal. Edinburgh: Edinburgh University Press.

Stedman, John Gabriel, 1796. Narrative of a Five Years' Expedition against the Revolted Negroes of Suriname. London: J. Johnson.

Swaminathan, Srividhya, 2009. Debating the Slave Trade: Rhetoric of British National Identity, 1759-1815. Burlington VT: Ashgate Publishing.

Sypher, Wylie, 1942. Guinea's Captive Kings: British Anti-Slavery Literature of the XvIIIth Century. Chapel Hill: University of North Carolina Press.

Thomas, Keith, 2018. In Pursuit of Civility: Manners and Civilization in Early Modern England. Waltham MA: Brandeis University Press.

Thomson, Ann, 2017. Colonialism, Race and Slavery in Raynal's Histoire des deux Indes. Global Intellectual History 2(3):251-67.

Thorne, R.G., 1970. Edwards, Bryan (1743-180o), of The Polygon, Southampton. In The History of Parliament. London: Secker \& Warburg, pp. 670-73.

Vendryes, H.E.E., 1945. Bryan Edwards. Jamaican Historical Review 1:76-82.

Waddell, David A.G., 1966. The British West Indies. In Robin W. Winks (ed.), The Historiography of the British Empire-Commonwealth: Trends, Interpretations, and Resources. Durham NC: Duke University Press, pp. 344-56. 
Walvin, James, 1972. The Black Presence: A Documentary History of the Negro in England, 1555-1860. New York: Schocken Books.

Wesley, John, 1774. Thoughts upon Slavery. Philadelphia: Joseph Crukshank.

Wilberforce, William, 1807. A Letter on the Abolition of the Slave Trade: Addressed to the Freeholders and Other Inhabitants of Yorkshire. London: T. Cadell and W. Davies.

Williams, Eric, 1944. Capitalism and Slavery. Chapel Hill: University of North Carolina Press.

Williamson, Karina, 2011. The Curious History of Bryan Edwards's Poems. Journal of the Edinburgh Bibliographical Society 6:74-88.

Wolf, Eva Sheppard, 2006. Race and Liberty in the New Nation: Emancipation in Virginia from the Revolution to Nat Turner's Rebellion. Baton Rouge: Louisiana State University Press.

Wood, Marcus, 2002. Slavery, Empathy, and Pornography. New York: Oxford University Press.

Wright, Philip (ed.), 1966. Lady Nugent's Journal of Her Residence in Jamaica from 1801 to 1805. Kingston: Institute of Jamaica.

Young, William, 1801. Prefatory Advertisement, in The History, Civil and Commercial, of the British Colonies in the West Indies, Vol. 1. London: T. Miller, pp. v-viii. 